\title{
ANALISIS FUZZY LOGIC MENENTUKAN PEMILIHAN MOTOR HONDA DENGAN METODE MAMDANI
}

\author{
Januardi Nasir ${ }^{1}$,Johnson Suprianto ${ }^{2}$ \\ ${ }^{12}$ Program Studi Teknik Informatika Universitas Putera Batam \\ Email: januardinasir@gmail.com \\ Submitted: 16-03-2017, Reviewed: 17 -03- 2017, Accepted 18-03-2017 \\ http://dx.doi.org/10.22202/jei.2017.v3i2.1962
}

\begin{abstract}
PT Indoprof Motor Sejati merupakan perusahaan dealer motor di Tanjung Uban. Dalam melakukan kegiatannya, PT Indoprof Motor Sejati perlu mempertimbangkan beberapa faktor pada saat melakukan pembelian motor. Namun,PT Indoprof Motor Sejati masih menggunakan cara manual dalam pengambilan keputusan terhadap pembelian motor tersebut. Hal ini dapat menimbulkan kerugian terhadap perusahaan. Untuk mengatasi masalah tersebut, maka dibutuhkan sebuah sistem yang dapat membantu pada pengambilan keputusan dalam pembelian motor. Dalam penelitian ini, pengambilan keputusan untuk membeli motor dilakukan dengan menggunakan logika fuzzy metode Mamdani. Dengan adanya sistem pengambilan keputusan dalam pembelian motor, diharapkan dapat membantu dan mempermudah PT Indoprof Motor Sejati dalam mengambil keputusan untuk membeli motor. Hasil dari penelitian ini dapat dilihatkan bahwa proses dari Matlab motor Beat menunjukkan $23.3 \%$ dan hasil defuzzifikasi hitung manual motor Beat menunjukkan $24.049 \%$, proses dari Matlab motor Vario menunjukkan $79.4 \%$ dan hasil defuzzifikasi hitung manual motor Vario menunjukkan 83.88\%, proses dari Matlab motor Supra menunjukkan 23.2\% dan hasil defuzzifikasi hitung manual motor Supra menunjukkan 21.049\%. jadi hasil ini menunjukan motor Vario yang akan di beli.
\end{abstract}

Kata Kunci: Pengambilan keputusan untuk membeli motor, Logika Fuzzy, Metode Mamdani,

\section{PENDAHULUAN}

Sebuah usaha yang membawa keuntungan banyak untuk pemilik usaha tentunya sangat diinginkan oleh semua pengusaha. Penjualan motor pada perusahaan Indoprof Motor Sejati memiliki beberapa tipe motor.

Setiap setiap tipe terdapat angka penjualan yang berbeda-beda dan tidak memiliki hasil yang sama. Untuk menentukan tipe motor yang tertinggi, masih menjadi tanda tanya bagi pemilik perusahaan Indoprof Motor Sejati.

Karena beberapa tipe motor yang dijual pada perusahaan Indoprof Motor Sejati dan memiliki statistik penjualan yang berbeda. Beberapa motor yang terpopuler pada perusahaan Indoprof Motor Sejati yaitu Beat, Vario, Supra.
Pemilik perusahaan sering kebingungan akan tipe motor yang harusnya dibeli dari main dealer untuk dijual ke pasaran. Motor Honda memiliki banyak tipe dan banyak seri. Dikarena banyak tipe motor maka dalam pemilihan pembelian motor dari main dealer harus di pertimbangkan terlebih dahulu.

Dikarenakan jika tipe motor yang dibeli tidak laku atau tidak terjual dengan cepat maka perusahan akan menimbul kerugian. Sebagai contoh jika motor yang di beli kebanyakkan tipe motor yang besar misalnya Mega Pro yang agak susah di jual akan merugikan perusahan.

Penelitian ini bertujuan untuk mengetahui motor Beat, Vario, Supra yang di rekomendasi dengan Fuzzy Logic metode mamdani, untuk mengetahui cara penerapan logika fuzzy metode mamdani pada 
pemilihan motor, untuk menganalisi dan menpelajari jenis motor dan pemanfaatan berdasarkan rule - rule dan disesuaikan dengan desain aplikasi yang dibuat. Selain itu, penelitian ini juga bertujuan untuk mengetahui cara merancang suatu aplikasi fuzzy logic dalam bentuk sebuah software yang membahas tentang pemilihan motor.

Penelitian ini bermanfaat untuk membantu pengusaha dalam penentuan rekomendasi motor Honda dengan metode mamdani logika fuzzy, menambah wawasan dan pengetahuan cara kerja fuzzy logic metode mamdani dalam pemilihan motor Honda,

\section{Kecerdasan Buatan (Artificial Intelligence)}

Menurut Sutojo, dkk (2011: 1) kecerdasan buatan berasal dari bahasa inggris "Artificial Intelligence" atau disingkat AI, yaitu Intellingence adalah kata sifat yang berarti cerdas, sedangkan Artificial artinya buatan. Kecerdasan buatan yang dimaksud di sini merujuk pada mesin yang mampu berpikir, menimbang tindakan yang akan diambil, dan mampu mengambil keputusan seperti yang dilakukan oleh manusia.

\section{Fuzzy Logic}

Menurut Sutojo, dkk (2011: 211) konsep tentang logika fuzzy diperkenalkan oleh Prof. Lotfi Astor Zadeh pada 1962, Logika fuzzy adalah metodologi sistem control pemecahan masalah, yang cocok untuk diimplementasikan pada sistem, mulai dari sistem yang sederhana, sistem kecil, embedded system, jaringan PC, multichannel atau workstation berbasis akuisisi data, dan sistem control.

Dalam logika klasik dinyatakan bahwa segala sesuatu bersifat biner, yang artinya adalah hanya mempunyai dua kemungkinan, "Ya atau Tidak", "Benar atau Salah", "Baik atau Buruk" dan lain-lain. Oleh karena itu, sistem ini dapat mempunyai nilai keanggotaan 0 atau 1. Akan tetapi, dalam logika fuzzy memungkinkan nilai keanggotaan berada di antara 0 dan 1 . Artinya, bisa saja suatu keadaan mempunyai dua nilai "Ya dan Tidak", "Benar dan Salah", "Baik dan Buruk" secara bersamaan, namun besar nilainya tergantung pada bobot keanggotaan yang dimilikinya.

Bila dibandingkan dengan logika konvensional, kelebihan logika fuzzy adalah kemampuannya dalam proses penalaran secara bahasa sehingga dalam perancanganya tidak memerlukan persamaan matematik yang rumit.

Himpunan fuzzy memiliki dua atribut yaitu: (1) Linguistik, yaitu nama suatu kelompok yang mewakili suatu keadaan tertentu dengan menggunakan bahasa alami, misalnya DINGIN, SEJUK, PANAS mewakili variabel temperature, (2) Numeris, yaitu suatu nilai yang menunjukkan ukuran dari suatu variabel, misalnya $10,35,40$, dan sebagainya.

\section{Metode Mamdani}

Menurut Sutojo, dkk (2011: 235) Metode Mamdani paling sering digunakan dalam aplikasi-aplikasi karena strukturnya yang sederhana, yaitu menggunakan operasi MIN-MAX atau MAX-PRODUCT. Untuk mendapatkan output, diperlukan 4 tahapan berikut. (1) Fuzzyfikasi, (2) Pembentukan basis pengetahuan Fuzzy (rule dalam bentuk IF...THEN), (3) Aplikasi fungsi implikasi menggunakan fungsi MIN dan Komposisi antar-rule menggunakan fungsi MAX ( menghasilkan himpunan fuzzy baru), (4) Deffuzyfikasi menggunakan metode Centroid

\section{Variabel}

Sepeda motor adalah sebuah mesin yang terbuat dari ribuan komponen. Secara umum,pemilik dan pengguna sepeda motor berharap tidak ada kerusakan pada motor miliknya, namun permasalahan pada motor 
seringkali terjadi. Untuk mengatasi masalah yang mungkin terjadi pemilik dan pengguna motor setidaknya mampu mengetahui lebih kerusakan pada mesin motor sehingga dapat dilakukan penanganan dini.

Sepeda motor adalah kendaran beroda dua yang digerakkan oleh sebuah mesin. Letak kedua roda sebaris lurus dan pada kecepatan tinggi sepeda motor tetap stabil disebabkan oleh gaya giroskopik. Sedangkan pada kecepatan rendah, kestabilan atau keseimbangan sepeda motor bergantung kepada pengaturan setang oleh pengendara. Penggunaan sepeda motor di Indonesia sangat populer karena harganya yang relatif murah, terjangkau untuk sebagian besar kalangan dan penggunaan bahan bakarnya serta serta biaya operasionalnya cukup hemat.

Gambar 1. Kerangka Pemikiran

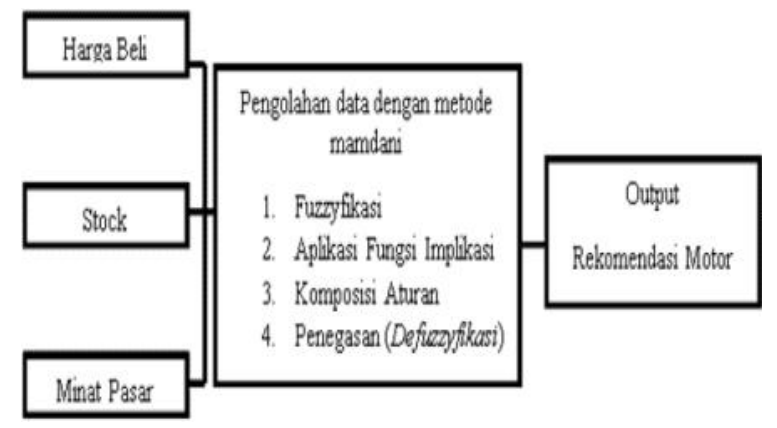

\section{METODE PENELITIAN Desain Penelitian}

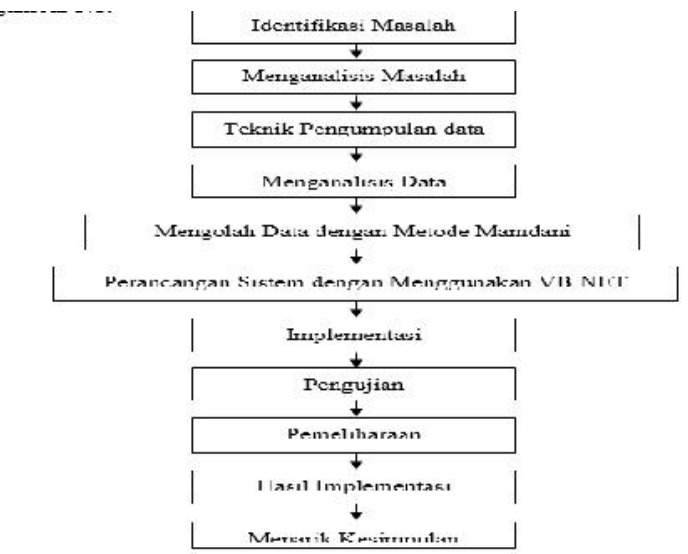

Sumber : Data Olahan (2017)

Gambar 2.Desain Penelitian
Tahapan penelitian yang dilakukan dalam penelitian ini, yaitu:

1. Identifikasi Masalah

Identifikasi masalah yang terjadi pada pembelian motor di PT Indoprof Motor Sejati

2. Menganalisis Masalah

Menganalisis masalah yang terjadi pada pembelian motor di PT Indoprof Motor Sejati.

3. Teknik Pengumpulan Data

Peneliti mengumpulkan data dan informasi yang diperlukan untuk mengetahui lebih terperinci masalah yang terjadi pada proses pembelian motor di PT Indoprof Motor Sejati.

4. Mengolah Data menggunakan Metode Mamdani

Data yang telah dikumpulkan oleh peneliti diolah menggunakan metode mamdani dari logika fuzzy

5. Perancangan Sistemdengan Menggunakan VB .NET

Merancang Sistem dengan menggunakan VB .NET untuk menyelesaikan masalahyang terjadi proses pembelian motor di PT Indoprof Motor Sejati.

6. Implementasi dengan VB .NET

Data yang telah diolah menggunakan metode mamdani diterapkan menggunakan VB.NET.

7. Pengujian

Setelah di rancang sistem dan akan dilalukan pengujian supaya sistem dijalankan dengan lancar.

8. Pemeliharaan

Pemeliharaan sangat diperlukan dalam perancangan sistem dikarenakan

9. Hasil Implementasi

Setelah data diimplementasi pada software MatLab dan VB .NET, maka muncul hasil penerapan tersebut.

10. Menarik Kesimpulan

Dari semua tahapan yang dilakukan peneliti dalam penelitian ini, tahapan terakhir yang dilakukan yaitu menarik 
kesimpulan dari penelitian yang telah dilakukan, yang memberikan penjelasan masalah yang terjadi pada proses pembelian motor di PT Indoprof Motor Sejati.

\section{HASILDAN PEMBAHASAN Analisis Data}

Fuzzy inference system (FIS) penelitian ini terdiri dari tiga variabel input dan satu variabel output. Variabel input yaitu Harga Beli, Stock, MinatPasar Serta variabel output yaitu Rekomendasi.

Data-data motor adalah berdasarkan hasil dari wawancara dilokasi PT Indoprof Motor Sejait penulis mendapat data-data seperti tabel 4.1.

\section{Tabel1Data-Data Harga Pembelian}

\begin{tabular}{|l|r|}
\hline Jenis Motor & Harga Beli \\
\hline Beat & 11.859 .441 \\
\hline Blade & 12.954 .107 \\
\hline CB & 20.366 .545 \\
\hline CBR & 27.569 .849 \\
\hline Mega Pro & 17.014 .970 \\
\hline Revo & 11.017 .770 \\
\hline Scoopy & 13.264 .390 \\
\hline Sonic & 17.207 .610 \\
\hline Spacy & 11.141 .920 \\
\hline Supra & 14.977 .260 \\
\hline Vario & 14.167 .109 \\
\hline Verza & 14.715 .085 \\
\hline
\end{tabular}

Sumber: Data Penelitian (2017)

Semesta pembicaraan adalah untuk menentukan domain yang sesuai hasil di indikator, Fuzzy inference system FIS dibutuhkan semesta pembicaraan. seperti tabel 2

\section{Tabel 2Semesta Pembicaraan}

\begin{tabular}{|c|l|c|c|}
\hline $\begin{array}{c}\text { Variab } \\
\text { el }\end{array}$ & Indikator & $\begin{array}{c}\text { Domai } \\
\text { n }\end{array}$ & $\begin{array}{c}\text { Keterang } \\
\text { an }\end{array}$ \\
\hline \multirow{3}{*}{ Input } & Harga Beli & $0-25$ & $1=1$ juta \\
\cline { 2 - 4 } & Stock & $0-40$ & $1=1$ Unit \\
\cline { 2 - 4 } & $\begin{array}{l}\text { Minat } \\
\text { Pasar }\end{array}$ & $0-40$ & $\%$ \\
\hline \multirow{2}{*}{ Output } & $\begin{array}{l}\text { Rekomenda } \\
\text { si }\end{array}$ & $0-100$ & $\%$ \\
\hline
\end{tabular}

Sumber: Data Penelitian (2017)

Himpunan fuzzy yang dibuat untuk tiap variabel input dan outputberdasarkan data dari PT Indoprof Motor Sejati seperti tabel 3

\begin{tabular}{|c|c|c|c|c|}
\hline Variabel & Indikator & Himpunan & Domain & MF type \\
\hline \multirow{9}{*}{ Input } & \multirow{3}{*}{ Harga Beli } & Murah & {$\left[\begin{array}{llll}0 & 0 & 5 & 10\end{array}\right]$} & Trapmf \\
\hline & & Sedang & {$\left[\begin{array}{lll}8 & 13 & 18\end{array}\right]$} & Trimf \\
\hline & & Mahal & {$\left[\begin{array}{llll}16 & 21 & 25 & 25\end{array}\right]$} & Trapmf \\
\hline & \multirow{3}{*}{ Stock } & Sedikit & {$\left[\begin{array}{lllll}0 & 0 & 10 & 15\end{array}\right]$} & Trapmf \\
\hline & & Sedang & {$\left[\begin{array}{lll}13 & 20 & 27\end{array}\right]$} & Trimf \\
\hline & & Banyak & {$\left[\begin{array}{lllll}25 & 33 & 40 & 40\end{array}\right]$} & Trapmf \\
\hline & \multirow{3}{*}{ Minat Pasar } & Rendah & {$\left[\begin{array}{llll}0 & 0 & 1 & 0\end{array}\right]$} & Trapmf \\
\hline & & Sedang & {$\left[\begin{array}{lll}13 & 20 & 27\end{array}\right]$} & Trimf \\
\hline & & Tinggi & {$\left[\begin{array}{lllll}25 & 33 & 40 & 40\end{array}\right]$} & Trapmf \\
\hline \multirow{2}{*}{ Outp̣ut } & \multirow{2}{*}{ Rekomendasi } & Tidak Beli & {$\left[\begin{array}{llll}0 & 0 & 25 & 55\end{array}\right]$} & Trapmf \\
\hline & & Beli & {$\left[\begin{array}{lllll}50 & 75 & 100 & 100\end{array}\right]$} & Trapmf \\
\hline
\end{tabular}

Sumber: Data Penelitian (2017)

\section{Proses Inferensi}

[R2] IF Harga Beli is Murah, AND Stock is Sedikit, AND Minat Pasar is Rendah,THEN Rekomendasi Tidak Beli

[R3] IF Harga Beli is Murah, AND Stock is Sedikit, AND Minat Pasar is Sedang,THEN Rekomendasi Beli

[R5] IF Harga Beli is Murah, AND Stock is Sedikit, AND Minat Pasar is Tinggi, THEN Rekomendasi Beli

[R8] IF Harga Beli is Murah, AND Stock is Sedang, AND Minat Pasar is Rendah,THEN Rekomendasi Tidak Beli 
[R9] IF Harga Beli is Murah, AND Stock is Sedang, AND Minat Pasar is Sedang,THEN Rekomendasi Beli

[R11] IF Harga Beli is Murah, AND Stock is Sedang, AND Minat Pasar is Tinggi,THEN Rekomendasi Beli

[R14] IF Harga Beli is Murah, AND Stock is Banyak, AND Minat Pasar is Rendah,THEN Rekomendasi Tidak Beli

[R16] IF Harga Beli is Murah, AND Stock is Banyak, AND Minat Pasar is Sedang,THEN Rekomendasi Tidak Beli

[R17] IF Harga Beli is Murah, AND Stock is Banyak, AND Minat Pasar is Tinggi,THEN Rekomendasi Beli

[R20] IF Harga Beli is Sedang, AND Stock is Sedikit, AND Minat Pasar is Rendah,THEN Rekomendasi Tidak Beli

[R21] IF Harga Beli is Sedang, AND Stock is Sedikit, AND Minat Pasar is Sedang,THEN Rekomendasi Beli

[R23] IF Harga Beli is Sedang, AND Stock is Sedikit, AND Minat Pasar is Tinggi,THEN Rekomendasi Beli

[R26] IF Harga Beli is Sedang, AND Stock is Sedang, AND Minat Pasar is Rendah,THEN Rekomendasi Tidak Beli

[R28] IF Harga Beli is Sedang, AND Stock is Sedang, AND Minat Pasar is Sedang,THEN Rekomendasi Tidak Beli

[R29] IF Harga Beli is Sedang, AND Stock is Sedang, AND Minat Pasar is Tinggi,THEN Rekomendasi Beli

[R32] IF Harga Beli is Sedang, AND Stock is Banyak, AND Minat Pasar is Rendah,THEN Rekomendasi Tidak Beli

[R34] IF Harga Beli is Sedang, AND Stock is Banyak, AND Minat Pasar is Sedang,THEN Rekomendasi Tidak Beli
[R35] IF Harga Beli is Sedang, AND Stock is Banyak, AND Minat Pasar is Tinggi,THEN Rekomendasi Beli

[R38] IF Harga Beli is Mahal, AND Stock is Sedikit, AND Minat Pasar is Rendah,THEN Rekomendasi Tidak Beli

[R39] IF Harga Beli is Mahal, AND Stock is Sedikit, AND Minat Pasar is Sedang,THEN Rekomendasi Beli

[R41] IF Harga Beli is Mahal, AND Stock is Sedikit, AND Minat Pasar is Tinggi,THEN Rekomendasi Beli

[R44] IF Harga Beli is Mahal, AND Stock is Sedang, AND Minat Pasar is Rendah,THEN Rekomendasi Tidak Beli

[R46] IF Harga Beli is Mahal, AND Stock is Sedang, AND Minat Pasar is Sedang,THEN Rekomendasi Tidak Beli

[R47] IF Harga Beli is Mahal, AND Stock is Sedang, AND Minat Pasar is Tinggi,THEN Rekomendasi Beli

[R50] IF Harga Beli is Mahal, AND Stock is Banyak, AND Minat Pasar is Rendah,THEN Rekomendasi Tidak Beli

[R52] IF Harga Beli is Mahal, AND Stock is Banyak, AND Minat Pasar is Sedang,THEN Rekomendasi Tidak Beli

[R53] IF Harga Beli is Mahal, AND Stock is Banyak, AND Minat Pasar is Tinggi,THEN Rekomendasi Beli

\section{Tabel 2. Data Pembelian, Stock, Minat} Pasar

\begin{tabular}{|c|c|c|c|}
\hline $\begin{array}{c}\text { Jenis } \\
\text { Motor }\end{array}$ & Harga Beli & Stock & $\begin{array}{c}\text { Minat } \\
\text { Pasar }\end{array}$ \\
\hline Beat & 11.859 .411 & 37 & $23,08 \%$ \\
\hline Vario & 14.167 .109 & 22 & $33,36 \%$ \\
\hline Supra & 14.977 .260 & 17 & $3,56 \%$ \\
\hline
\end{tabular}

Sumber : Data Penelitian (2017) 


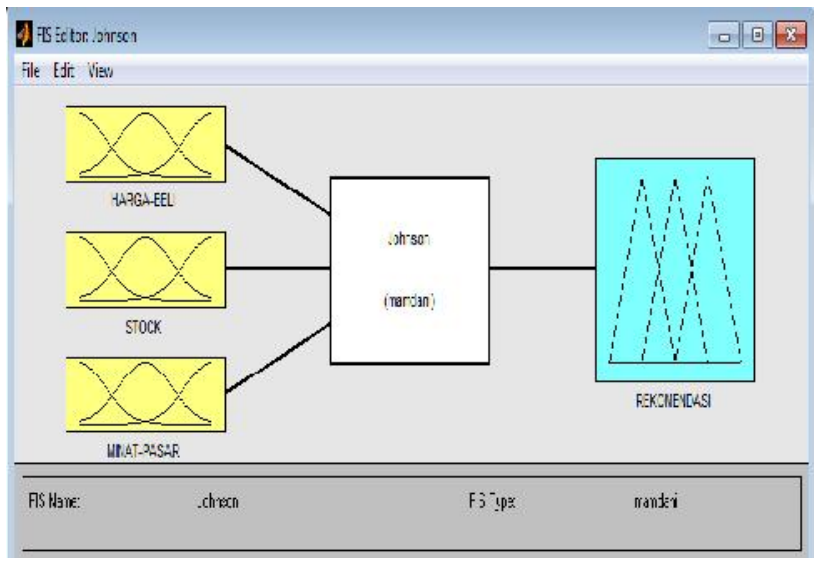

Gambar 3. Variabel input dan output Mamdani

\section{Implementasi Sistem Pada Matlab dan Defuzzyfikasi}

1. Rule Viewer Mamdani proses dari Matlab Motor Beat

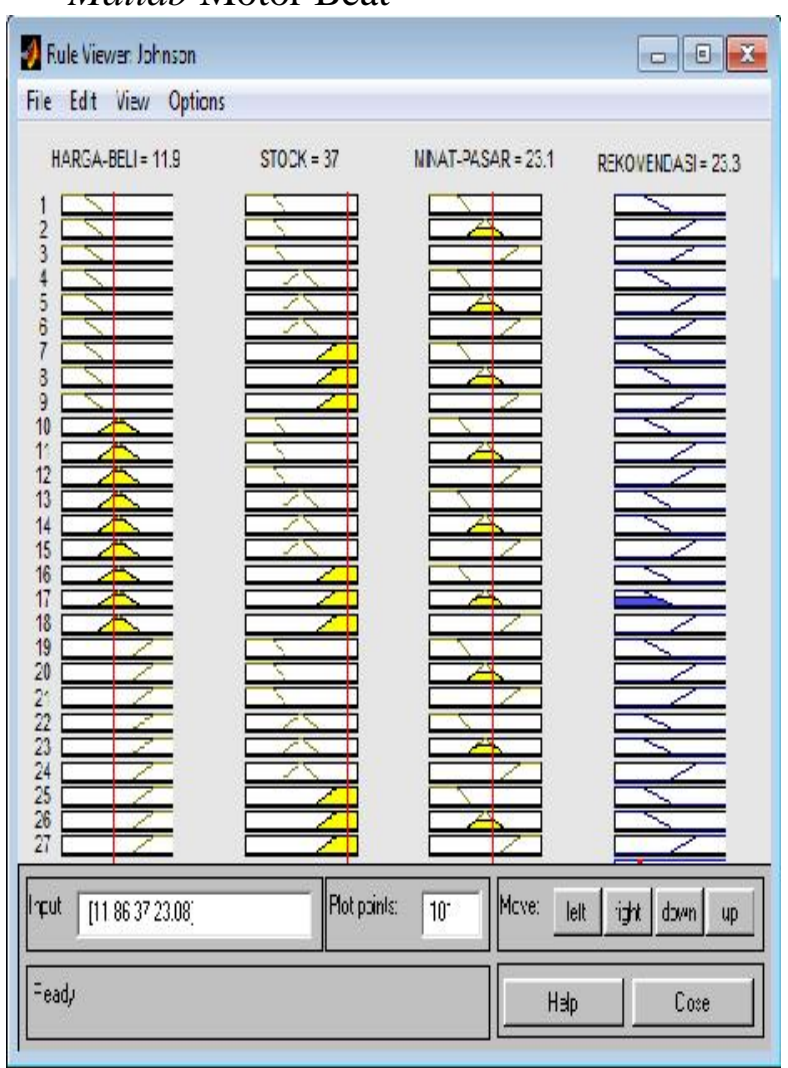

Gambar 4. Rule Viewer Mamdani (Beat)
[R 32] Beat

$$
\begin{aligned}
M 1= & \int_{0}^{48.1}(0.23) z d z=0.115 z^{2} \\
& =0.115(48.1)^{2}-0.115(0)^{2} \\
& =266.065-0
\end{aligned}
$$

$=266.065$

Kemudian hitung luas tiap daerah

$\mathrm{A} 1=0.23 * 48.1=11.063$

Titik pusat diperoleh dari

$Z=\frac{266.055}{11.063}$

$\mathrm{Z}=24.049$

2. Rule Viewer Mamdani proses dari Matlab Motor Vario

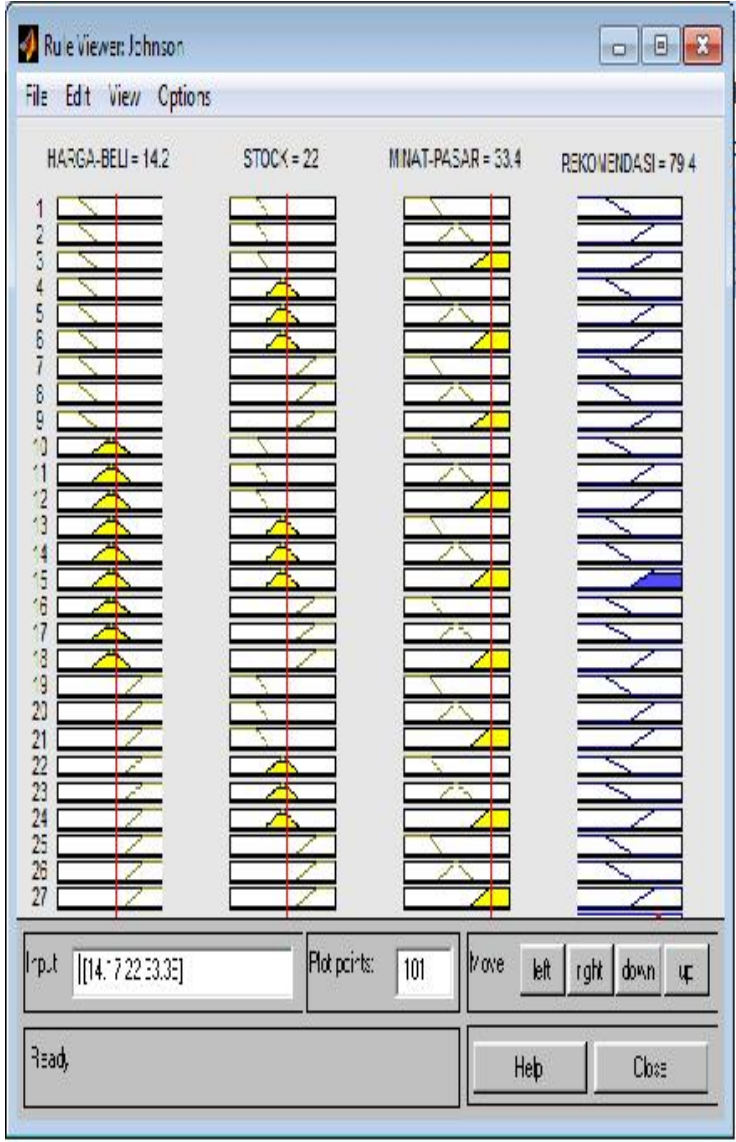

Gambar 5. Rule Viewer Mamdani (Vario) 
[R 29] Vario

$$
\begin{aligned}
\text { M1 } & =\int_{67.75}^{100}(0.71) z d z=0.355 z^{2} \\
& =0.355(100)^{2}-0.355(67.75)^{2} \\
& =3,550-1,629.472 \\
& =1,920.528
\end{aligned}
$$

Kemudian hitung luas tiap daerah

$\mathrm{A} 1=(100-67.75) * 0,71=22.896$

Titik pusat diperoleh dari

$$
\begin{aligned}
& Z=\frac{1,920.528}{22.896} \\
& Z=83.88
\end{aligned}
$$

3. Rule Viewer Mamdani proses dari Matlab Motor Supra

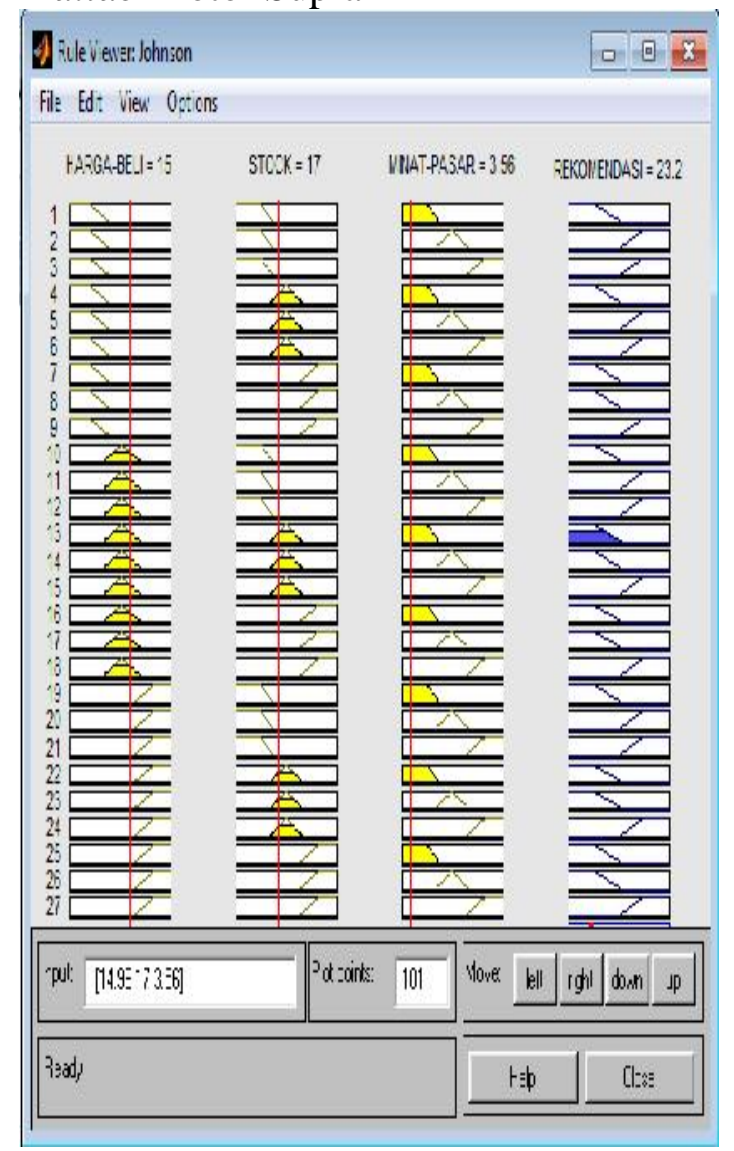

Gambar 6. Rule Viewer Mamdani (Supra)
[R 26] Supra

$$
\begin{aligned}
\text { M1 }=\int_{0}^{4 z, 1}(0.43) z d z=0.215 z^{2} \\
=0.215(42.1)^{2}-0.215(0)^{2} \\
=381.068-0=381.068
\end{aligned}
$$

Kemudian hitung luas tiap daerah

$\mathrm{A} 1=0.43 * 42.1=18.103$

Titik pusat diperoleh dari

$$
\begin{aligned}
& Z=\frac{381.068}{18.103} \\
& Z=21.0
\end{aligned}
$$

Hasil defuzzifikasi Rule Viewer Mamdani proses dari Matlab motor Beat menunjukkan $23.3 \%$ berada di range Rekomendasi Tidak Beli [ $\left[\begin{array}{llll}0 & 0 & 25 & 55\end{array}\right]$ dan hasil defuzzifikasi hitung manual motor Beat menunjukkan $24.049 \%$, motor Vario menunjukkan $79.4 \%$ berada di range Rekomendasi Beli [50 75100 100] dan hasil defuzzifikasi hitung manual motor Beat menunjukkan $83.88 \%$, motor Supra menunjukkan $23.2 \%$ berada di range Rekomendasi Tidak Beli [ [ $\left.\begin{array}{llll}0 & 0 & 25 & 55\end{array}\right]$ dan hasil defuzzifikasi hitung manual motor Supra menunjukkan $21.049 \%$

\section{Implementasi Sistem Pada Visual basic}

\section{a. Form Login}

Form login terdiri Username dan Password, setelah masukan username dan password akan melanjutkan ke Menu_ Utama

Username : Admin / user

Passoword : Admin / 123456 


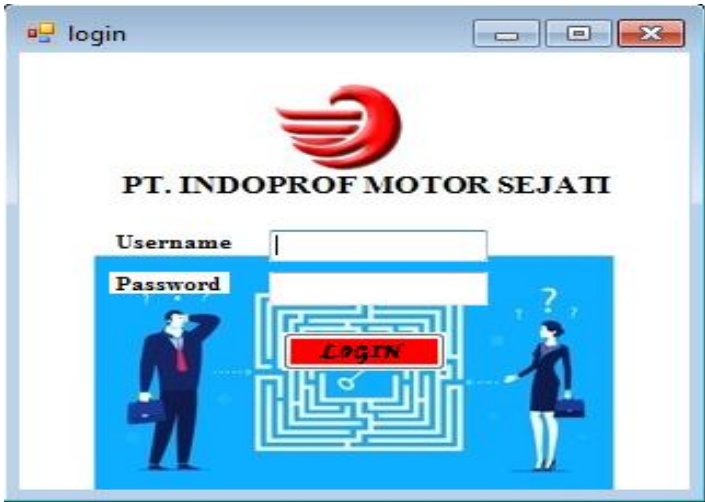

Gambar 7. Form Login

b. Menu Utama

Menu utama terdiri file, transaksi, kelola, di menufile terdapat fitur logout dan exit, dan menu transaksi terdapat fitur proses untuk melanjutkan ke form jenis motor, dan menu kelola terdapat fitur kelola $u$ ser.

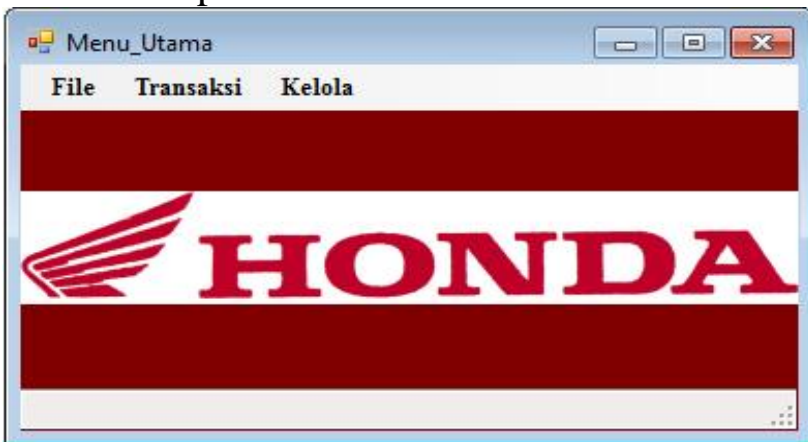

Gambar 8. Menu Utama

c. Jenis Motor

Di menu transaksi terdapat fitur proses, setelah di pilih fitur proses akan menuju ke form jenis motor.

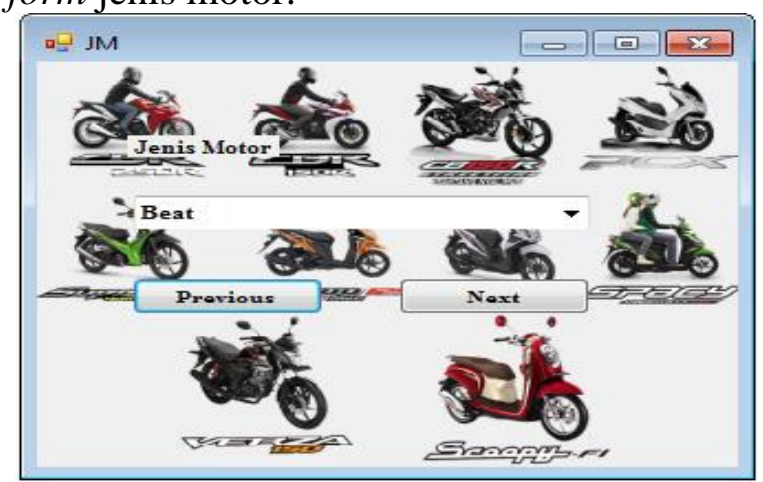

Gambar 9. Form Jenis Motor d. Harga Beli

Di form harga beli kita dapat memilih 3 jenis harga yaitu: Murah, Sedang, Mahal. Klik next ke form berikut, klik previous ke form sebelumnya

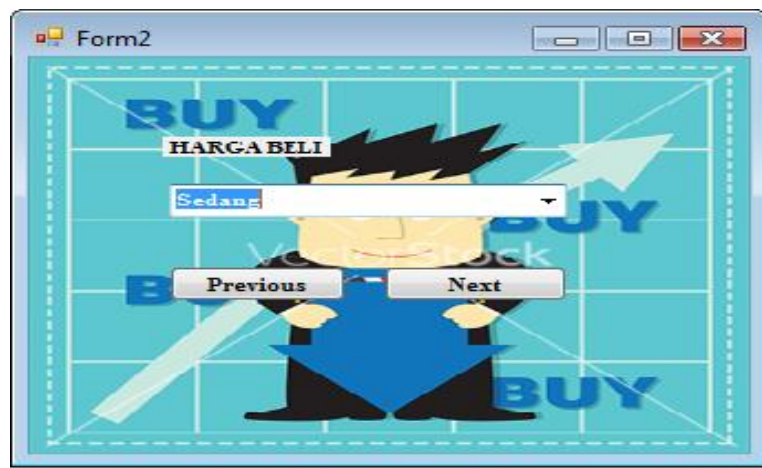

Gambar 10. Form Harga Beli

e. Stock

Di form stock kita dapat memilih 3 jenis pilihan yaitu: Sedikit, Sedang, Banyak. Klik next ke form berikut, klik previous ke form sebelumnya

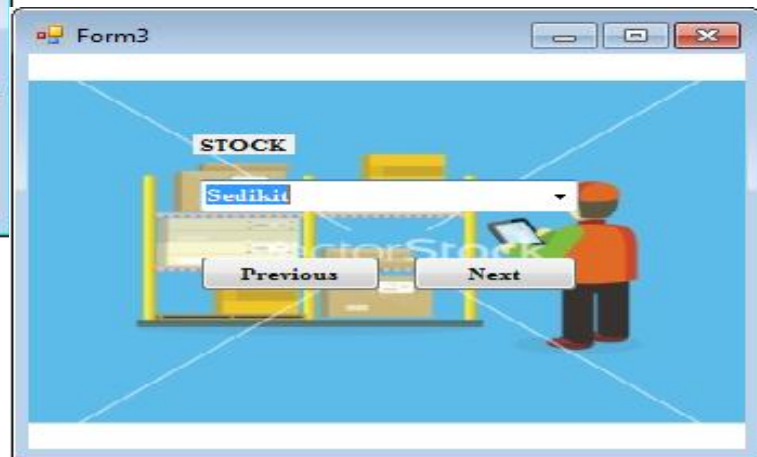

Gambar 11.Form Stock

f. Minat Pasar

Di form minat pasar kita dapat memilih 3 jenis pilihan yaitu: Rendah, Sedang, Tinggi. Klik submit ke form berikut, klik previous ke form sebelumnya 


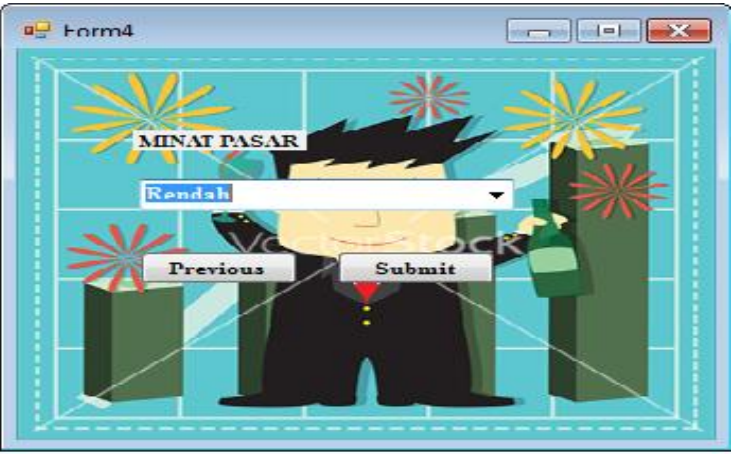

Gambar 12. Form Minat Pasar

g. Rekomendasi

Di form rekomendasi kita dapat hasil rekomendasi beli/tidak beli. Dan button reset menuju ke menu utama, dan close untuk menutup aplikasi.

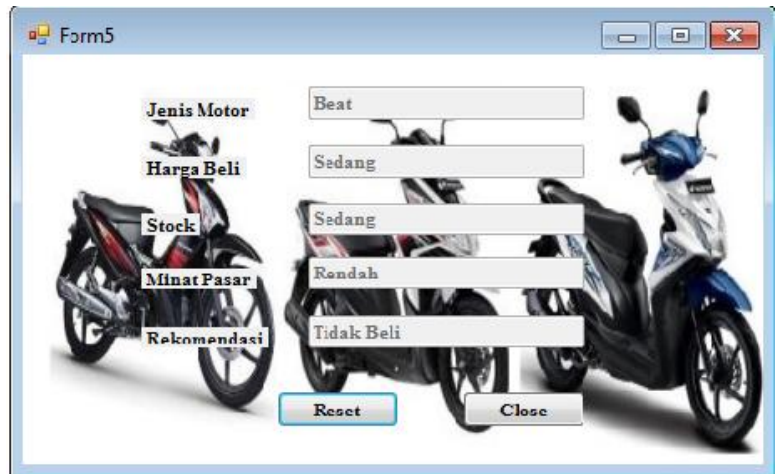

Gambar 13. Form Rekomendasi

h. Kelola User (m_user)

Form ini hanya admin yang berhak mengakses fitur ini, untuk mengelola user.

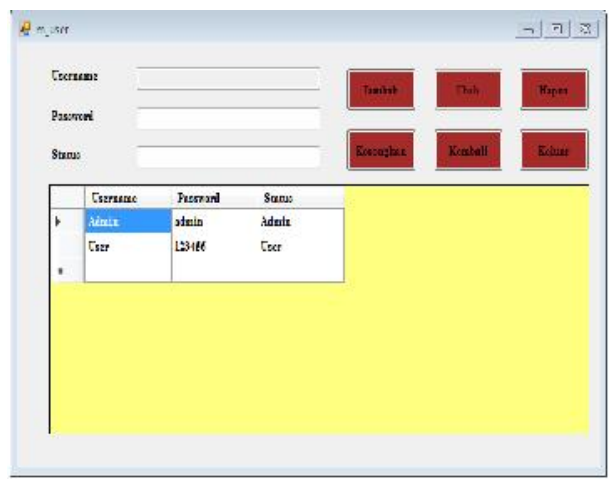

Gambar 14. Form m_user

\section{SIMPULAN}

Berdasarkan Pembahasan penelitian dan analisa telah yang dilakukan, maka dapat disimpulkan beberapa hal sebagai berikut :

1. Untuk menentukan motor yang rekomendasi antara Beat, Vario, Supra dengan menggunakan Matlab untuk menghasilkan rule-rule yang akan digunakan untuk menentukan Rekomendasi Beli atau Tidak dibeli

2. Untuk mengetahui cara menerapkan fuzzy logic metode mamdani pemilihan motor digunakan dengan software MATLAB.

3. Berdasarkan hasil penelitan dari tiga jenis motor diantara Motor Beat, Vario, dan Supra, menyimpulkan motor Vario ditentukan sebagai jenis yang direkomendasi karena dengan hasil defuzzyfikasi $83.88 \%$ dan hasil matlab $79.4 \%$.

4. Berdasarkan hasil aplikasi yang dibuat dengan visual basic untuk mendukung perusahan dalam menentukan pembelian motor.

\section{DAFTAR PUSTAKA}

Arifin, Saiful Much Aziz Muslim dan Sugiman (2015). Implementasi Logika Fuzzy Mamdani untuk Mendeteksi Kerentanan Daerah Banjir di Semarang Utara. 2 (2) :179- 192.

Hidayatullah, Priyanto. (2015).Visual Basic. NET membuat Aplikasi Database dan Program Kreatif, Informatika Bandung, Bandung.

Jayati, Sherly dan Sri Hartati, (2012). Sistem Pendukung Keputusan Seleksi Anggota Paduan Suara Dewasa Menggunakan Metode Fuzzy Mamdani . 1 (6) :55- 66.

Kusumadewi, Sri dan Hari Purnomo (2010) Aplikasi Logika Fuzzy Untuk Pendukung Keputusan Edisi Kedua. Graha Ilmu. Yogyakarta. 
Naba, Agus. (2009). Belajar cepat fuzzy logic menggunakan MATLAB, Andi Offset, Yogyakarta.

Nasution, Indah Akmal (2014). Sistem Pendukung Keputusan Penentuan Pemilihan Laptop Dengan Menerapkan Fuzzy Tahani. 1 (VI) : 93-96.

Sutisna, Herlan dan Noor Cholis Basjaruddin, (2015). Sistem Pendukung Keputusan Pemilihan Pekerjaan Menggunakan Metode
Fuzzy Mamdani Studi Kasus :Amik BSI Tasikmalaya. 2 (II) : 362- 375.

Sutojo, T., Mulyanto Edy. dan Suhartono Vincent, (2011). Kecerdasan Buatan. Edisi 1, Andi Offset, Yogyakarta.

Tauro, Stefi Priescha(2013), Jurnal Nasional Pendidikan Teknik Informatika (JANAPATI), Volume 1, Nomor 12, November 2013, ISSN 2337-6732, dengan Judul "Analisis Biaya Penggunaan Alat Berat Pada Perkerjaan Tanah". 